\title{
Correction to: Classical and lectin complement pathways and markers of inflammation for investigation of susceptibility to infections among healthy older adults
}

\author{
David C. LaFon ${ }^{1,2}$, Steffen Thiel ${ }^{3}$, Young-il Kim ${ }^{4}$, Mark T. Dransfield ${ }^{1,2,5}$ and Moon H. Nahm ${ }^{1,6 *}$
}

\section{Correction to: Immun Ageing 17, 18 (2020) https://doi.org/10.1186/s12979-020-00189-7}

Following publication of the original article [1], the authors reported an error in the 'Methods' section under the subheading entitled 'Complement and cytokine assays,' the description of assays should read as follows (change highlighted in bold below):

\section{"Assays for complement factors C3 and C4, C- reactive protein $(\mathrm{CRP})$, and classical pathway activity (CH50) were performed at the clinical laboratory at the University of Alabama at Birming- ham, using the respective Optilite turbidimetric assay kits (The Binding Site)."}

The original article [1] has been updated.

\begin{abstract}
Author details
'Division of Pulmonary, Allergy, and Critical Care, University of Alabama at Birmingham, Birmingham, AL, USA. ${ }^{2}$ UAB Lung Health Center, Birmingham, AL, USA. ${ }^{3}$ Department of Biomedicine, Aarhus University, Aarhus, Denmark. ${ }^{4}$ Division of Preventive Medicine, University of Alabama at Birmingham, Birmingham, AL, USA. ${ }^{5}$ Birmingham VA Medical Center, Birmingham, AL, USA. ${ }^{6}$ Department of Microbiology, University of Alabama at Birmingham, Bevill Building Room 614 (BBRB 614), 845 19th Street South, Birmingham, AL 35294, USA.
\end{abstract}

Published online: 07 August 2021

Reference

1. LaFon DC, Thiel S, Kim Y, et al. Classical and lectin complement pathways and markers of inflammation for investigation of susceptibility to infections among healthy older adults. Immun Ageing. 2020;17:18 https://doi.org/1 0.1186/s12979-020-00189-7.

The original article can be found online at https://doi.org/10.1186/s12979020-00189-7.

* Correspondence: nahm@uab.edu

${ }^{1}$ Division of Pulmonary, Allergy, and Critical Care, University of Alabama at Birmingham, Birmingham, AL, USA

${ }^{6}$ Department of Microbiology, University of Alabama at Birmingham, Bevill Building Room 614 (BBRB 614), 845 19th Street South, Birmingham, AL 35294, USA

C The Author(s). 2021 Open Access This article is licensed under a Creative Commons Attribution 4.0 International License, which permits use, sharing, adaptation, distribution and reproduction in any medium or format, as long as you give appropriate credit to the original author(s) and the source, provide a link to the Creative Commons licence, and indicate if changes were made. The images or other third party material in this article are included in the article's Creative Commons licence, unless indicated otherwise in a credit line to the material. If material is not included in the article's Creative Commons licence and your intended use is not permitted by statutory regulation or exceeds the permitted use, you will need to obtain permission directly from the copyright holder. To view a copy of this licence, visit http://creativecommons.org/licenses/by/4.0/ The Creative Commons Public Domain Dedication waiver (http://creativecommons.org/publicdomain/zero/1.0/) applies to the data made available in this article, unless otherwise stated in a credit line to the data. 